\title{
A GIS-based assessment of recent changes in drainage and morphometry of Betwa River basin and sub-basins, Central India
}

\author{
Madavi Venkatesh ${ }^{1} \cdot$ Anshumali $^{1}$ (D)
}

Received: 13 December 2018 / Accepted: 4 September 2019 / Published online: 16 September 2019

(c) The Author(s) 2019

\begin{abstract}
Morphometric characterization of the Betwa River basin (BRB) in Central India has been carried out to understand the spatial variations in morphometric parameters and evaluate hydrological, geological and topographical characteristics by analyzing SRTM DEM and topographical maps using geographic information system. Based on catchment characteristics and anthropogenic activities, the Betwa River basin and sub-basins were divided into three regions: (a) upstream, (b) midstream and (c) downstreams regions. The BRB comprised a dendritic drainage pattern where the maximum number of the stream was found in the first order. The mean bifurcation ratio (4.61) showed that the drainage pattern was not affected by structural disturbances. The drainage texture analysis showed the dominance of coarse texture, low runoff, low erosional potential, permeable subsurface material, high vegetation cover and low relief. The circularity ratio $(0.13)$ showed an elongated shape of the basin. The $>74.5 \%$ of the study area had $<3^{\circ}$ slope indicates gentle terrain condition. These results could be utilized in developing watershed management, agricultural land-use planning, forestry management and planning of sustainable industrial facilities.
\end{abstract}

Keywords Drainage · GIS · Betwa River basin · SRTM DEM · Morphometry

\section{Introduction}

In recent years, morphometric variables are largely used for watershed prioritization using remote sensing (RS) and geographic information system (GIS) techniques (Avinash et al. 2011; Samal et al. 2015). The urban and agricultural expansion, industrial activities and climate change (Singh et al. 2014; Abboud and Nofal 2017) have shown impacts on morphometric parameters of river basins (Panda et al. 2018). Morphometric parameters define the topographical, geological and hydrological condition of a basin (Angillieri 2012; Kabite and Gessesse 2018). The study on drainage system morphometry enhances the understanding of landform formation, soil physical properties, erosion characteristics and runoff discharge (Ameri et al. 2018).

Digital elevation model (DEM) is the primary dataset for various applications in topography, geomorphology,

Anshumali

malijnu@gmail.com

1 Laboratory of Biogeochemistry, Department of Environmental Science and Engineering, Indian Institute of Technology (ISM), Dhanbad, Jharkhand 826004, India vegetation cover studies, tsunami assessment, hydrology, morphometry and urban studies (Patel et al. 2016). DEMbased terrain visualization, processing and quantification of topographic attributes made GIS a powerful tool in morphometric studies (Kumar et al. 2017) to understand river basin structure and functions at local, regional and global scales (Thomas et al. 2011; Bali et al. 2012; Yadav et al. 2014). Geospatial studies revealed that Shuttle Radar Topography Mission digital elevation model (SRTM DEM) is much better in providing accurate data particularly for drainage morphometry and hydrological studies than Advanced Spaceborne Thermal Emission and Reflection Radiometer digital elevation model (ASTER DEM) (Kabite and Gessesse 2018). The SRTM DEM is based on the principle of interferometric SAR (InSAR), which uses phase difference measurements derived from two radar images acquired with a very small base-to-height ratio (typically 0.0002 ) to measure topography (SRTM project). The SRTM global data for the rest of the world other than the USA is available at 3-arc second $(90 \mathrm{~m})$.

Many river basins of ecological importance in the Asian countries are yet to be characterized to decipher their 
carrying capacity for long-term sustainability of the natural and man-made ecosystems.

Betwa River basin (BRB) is historically one of the oldest running water systems that witnessed the dawn of human civilization in the Indian subcontinent. In this study, the Betwa River basin is divided into three regions: (a) the upstream region is characterized by heavy industrialization and urbanization, (b) the midstream region stream is rural Central India and major agricultural region for the cultivation of pulses (beans, chickpeas and lentils), and (c) the downstream region is characterized by stone crushing, granite industries and thermal power plants. These man-made activities are associated with the direct discharge of mine water, wastewater, increased sedimentation, dust deposition, soil erosion and flooding. In view of this, the spatial variations in drainage and morphometric parameters (linear, aerial, drainage texture and relief aspects) were studied to describe and evaluate hydrological, geological and topographical characteristics by analyzing SRTM DEM and topographical maps of the Betwa River basin and sub-basins using GIS techniques. The yearly changes in precipitation pattern for 30 years were carried out by SWAT analysis.

\section{Materials and methods}

\section{Study area}

The Betwa is a major tributary of Yamuna River having SW to NE flow direction in the Bundelkhand region of Central India, situated between latitudes $77^{\circ} 15^{\prime}$ and $79^{\circ} 45^{\prime} \mathrm{N}$ and longitudes $23^{\circ} 5^{\prime}$ and $25^{\circ} 55^{\prime} \mathrm{E}$, draining the total area of about $44,002 \mathrm{~km}^{2}$ of which $68.84 \%$ is in Madhya Pradesh and $32.16 \%$ in Uttar Pradesh (Fig. 1). The
Dehgaon Bamori Forest Range is ecologically sensitive for the origin of Betwa River in Raisen District at an elevation of $475 \mathrm{~m}$ above mean sea level (msl) and joins river Yamuna near Hamirpur in Uttar Pradesh, traveling a total distance of about $564 \mathrm{~km}$. The origin of major upstream tributaries mainly Kaliasot, Halali, Sagar and Bina also occurs from the Dehgaon Bamori Forest Range; the midstream tributaries are Narain, Orr and Jamni originating from Guna and Lalitpur Forest Range; Dhasan and Birma are major tributaries in downstream of Betwa River. The average annual rainfall is $1138 \mathrm{~mm}$, the average annual evaporation loss is $1830 \mathrm{~mm}$, and the average annual runoff is about 13,430 million cubic meters (MCM), out of which nearly $80 \%$ occurs in monsoon.

The Betwa River basin is in saucer shape with sandstone hills around its periphery and is covered by three major group of rocks of different ages: the Bundelkhand complex (older than 2.6 billion years), the Bijawar group (2.6-2.4 billion years) and the Vindhyan Supergroup (1.4-0.9 billion years). The northern portion is covered with alluvial soils, the central part contains mixed red sandy and black soils, and the southern part has medium black soils. Bundelkhand craton comprises of granitoids, syenites, amphibolites, banded iron formation, tonalite-trondhjemite-granodiorite, gneisses, calc-silicate rocks, quartzites, pillow lavas, basaltic metasediments and giant quartz veins (Malviya et al. 2006; Pati et al. 2007). The Bijawar group is the Mesoproterozoic formations deposited over the Archean Bundelkhand craton, and it is exposed along its southeastern (Hirapur and Sonarai Basins) and northwestern (Gwalior Basin) margins. These rocks are again well exposed along the southeastern edges of the Vindhyan Syncline where they dip under the Semri Group of the Vindhyan Supergroup (Ray 2006). (a)

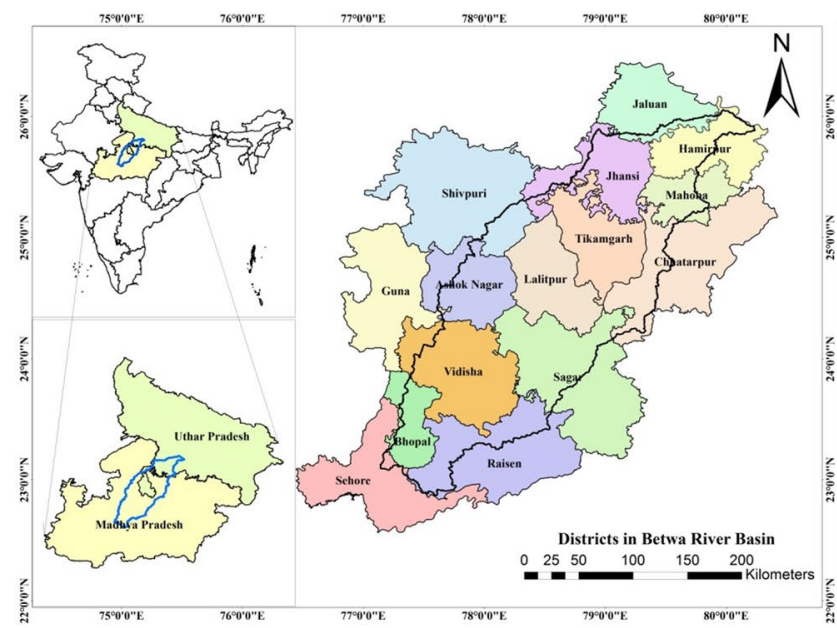

(b)

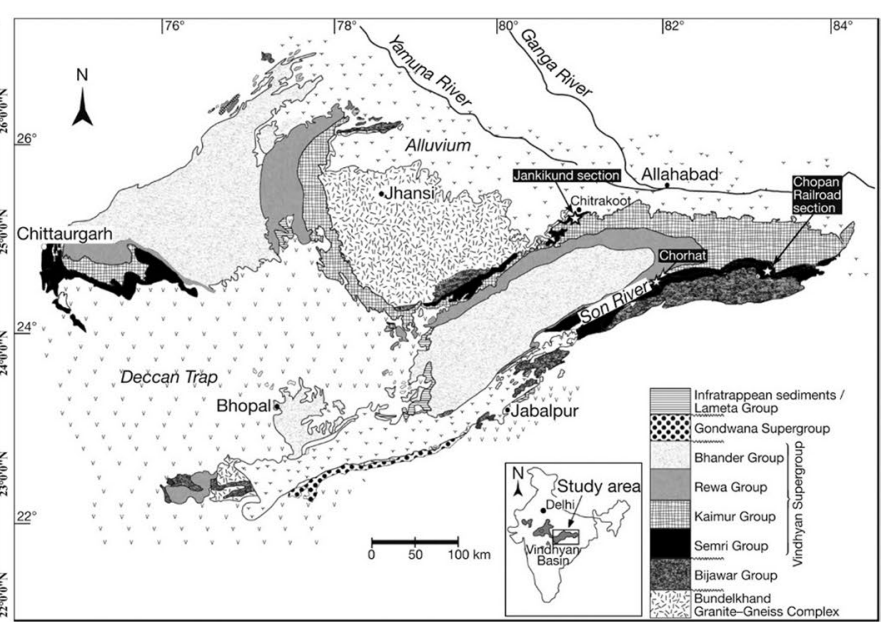

Fig. 1 Betwa River basin: a location map and $\mathbf{b}$ geology of the study area 


\section{Morphometric analysis}

In the present study, an integrated use of DEM and survey of India topographical sheets were utilized for the generation of database and extraction of various drainage parameters. Details of data used are listed in Table 1. The following procedure was used for morphometric parameter extraction and analysis which is shown in Fig. 2:

(a) The SOI toposheets were geometrically rectified and georeferenced by taking ground control points (GCPs) by using the Universal Transverse Mercator (UTM) projections and the World Geodetic System (WGS) 1984UTM Zone 43 datum. Further, all geocoded toposheets were mosaic using Arc GIS 10.2 software.

(b) The catchment area of the Betwa River basin delineated from SRTM DEM and Survey of India topographical sheets of the study area using spatial analyst tool of Arc GIS by selecting AOI (area of interest).

(c) The DEM of the catchment was extracted from Shuttle Radar Topography Mission (SRTM) data obtained with a resolution of $90 \mathrm{~m}$ (downloaded from the http://srtm. csi.cgiar.org). SRTM is a single pass, synthetic aperture radar interferometry (InSAR) campaign which provides unique DEM data with $90 \mathrm{~m}$ resolution (Rabus et al. 2003). (d) The SRTM DEM is utilized to prepare topographic, slope and delineation of the drainage map of the basin using the hydrology tool of Arc GIS 10.2. This extracted DEM is used to calculate morphometric parameters of the Betwa River and its tributaries.

(e) All the extracted parameters as the number and length of streams with different stream order, drainage area, basin perimeter, total basin length and width were calculated using Arc GIS software. Drainage density, drainage texture, stream frequency, shape, circulatory ratio, elongation ratio, etc., were calculated from these parameters. The summary of methodologies adopted for the computation of morphometric parameters is given in Table 2.

\section{Results and discussion}

\section{Linear aspects}

The results of linear morphometric attributes of Betwa River basin and its sub-basin are given in Table 3. Stream order $(U)$ is defined as a measure of the position of a stream, stream size and drainage area (Leopold et al. 1964; Strahler 1957). The stream number $(\mathrm{Nu})$ is defined as a number of streams in each order which is inversely proportional to

Table 1 Data used in the present work

\begin{tabular}{llll}
\hline S1. no. & Type of data/software & Detail of data & Sources \\
\hline 1. & Toposheet & $54 \mathrm{E} / 3,54 \mathrm{H} / 15-16,54 \mathrm{~K} / 4,54 \mathrm{~K} / 8,54 \mathrm{~K} / 10-14,54 \mathrm{~L} / 2,54 \mathrm{~L} / 4-6,54 \mathrm{~L} / 8-9$, & Survey of India(SOI), \\
& & $54 \mathrm{~L} / 11-13,54 \mathrm{~L} / 16,54 \mathrm{~L} / 2,54 \mathrm{O} / 1-2,54 \mathrm{O} / 5-6,54 \mathrm{P} / 2,54 \mathrm{P} / 4-5,54 \mathrm{Q} / 3,54 \mathrm{Q} / 4$, & Dehradun, India \\
& & $54 \mathrm{Q} / 7-8,55 \mathrm{E} / 2-7,55 \mathrm{E} / 9-16,55 \mathrm{~F} / 1,55 \mathrm{~F} / 5,55 \mathrm{~F} / 9,55 \mathrm{~F} / 13,55 \mathrm{I} / 1-10$ & http://srtm.csl.cgiar.org \\
2. & SRTM DEM & $3 \mathrm{ARC}(90 \mathrm{~m})$ & www.glovis.usgs.gov \\
3. & Landsat 7 satellite & Path/row: 144/42, 144/43, 144/44,145/42, 145/43, 145/44 dated 24/11/2016 & \\
& imagery (Row and & & \\
& path) & & \\
\hline
\end{tabular}

Fig. 2 Steps involved in drainage morphometry analysis

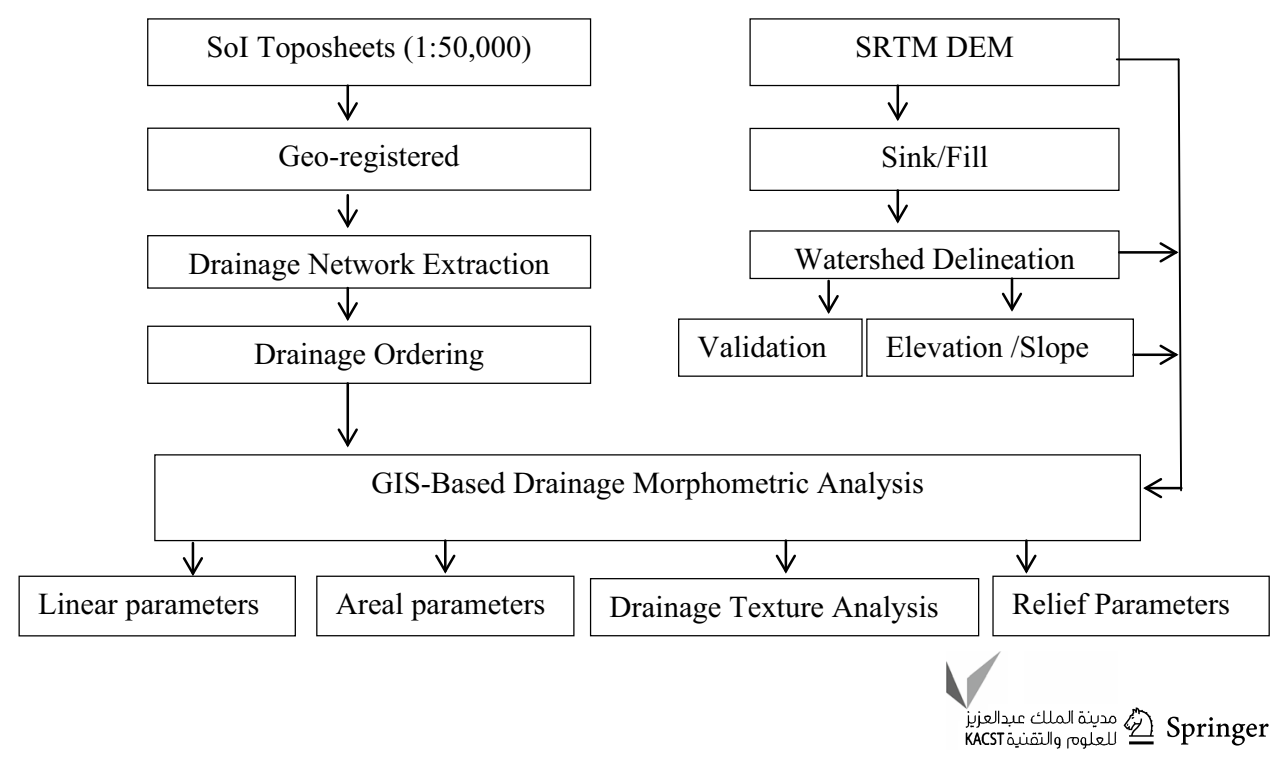


Table 2 Methodology adopted for computation of morphometric parameters

\begin{tabular}{|c|c|c|c|}
\hline \multirow[t]{2}{*}{ S. no. } & \multicolumn{3}{|l|}{ Linear parameters } \\
\hline & Parameters & Formula & References \\
\hline 1 & Stream order $(U)$ & Hierarchical rank & Strahler (1952) \\
\hline 2 & Stream number $(\mathrm{Nu})$ & $\mathrm{Nu}=\mathrm{N} 1+\mathrm{N} 2+\ldots \ldots .+\mathrm{Nn}$ & Horton (1945) \\
\hline 3 & Stream length $(\mathrm{Lu})(\mathrm{km})$ & Length of the stream & Strahler (1964) \\
\hline 4 & Mean stream length (km) (Lsm) & $\mathrm{Lsm}=\mathrm{Lu} / \mathrm{Nu}$ & Strahler (1964) \\
\hline 5 & Stream length ratio (Lur) & $\operatorname{Lur}=\mathrm{Lu} /(\mathrm{Lu}-1)$ & Strahler (1964) \\
\hline 6 & Bifurcation ratio $(\mathrm{Rb})$ & $\mathrm{Rb}=\mathrm{Nu} / \mathrm{Nu}+1$ & Strahler (1964) \\
\hline 7 & Rho coefficient $(\rho)$ & $\rho=\mathrm{Lur} / \mathrm{Rb}$ & Horton (1945) \\
\hline 8 & $\begin{array}{l}\text { Mean bifurcation ratio }(\mathrm{Rbm}) \\
\text { Areal parameters }\end{array}$ & $\mathrm{Rbm}=(\mathrm{Rb} 1+\mathrm{Rb} 2 \ldots+\mathrm{Rbn}) / n$ & Strahler (1964) \\
\hline 9 & Perimeter $(P)(\mathrm{km})$ & GIS analysis/DEM & Schumm (1956) \\
\hline 10 & Basin length (Lb) (km) & GIS analysis/DEM & Schumm (1956) \\
\hline 12 & Basin area $(A)\left(\mathrm{km}^{2}\right)$ & GIS analysis/DEM & Schumm (1956) \\
\hline 13 & Mean basin width (Wb) & $\mathrm{Wb}=A / \mathrm{Lb}$ & Horton (1932) \\
\hline 14 & Lemniscate's $(k)$ & $k=L b^{2} / A$ & Chorley (1957) \\
\hline 15 & $\begin{array}{l}\text { Form factor ratio }(\mathrm{Rf}) \\
\text { Drainage texture analysis }\end{array}$ & $\mathrm{Ff}=A / L^{2}$ & Horton (1932) \\
\hline 16 & Drainage density (Dd) & $\mathrm{Dd}=\mathrm{Lu} / A$ & Horton (1932) \\
\hline 17 & Stream frequency $\left(F_{\mathrm{s}}\right)$ & $F_{\mathrm{s}}=\mathrm{Nu} / A$ & Horton (1932) \\
\hline 18 & Drainage texture (Dt) & $\mathrm{Dt}=\mathrm{Nu} / \mathrm{P}$ & Horton (1945) \\
\hline 19 & Circularity ratio $(\mathrm{Rc})$ & $\mathrm{Rc}=12.57 *\left(A / P^{2}\right)$ & Miller (1953) \\
\hline 20 & Constant of channel maintenance $(C)$ & $C=1 / \mathrm{Dd}$ & Schumm (1956) \\
\hline 21 & $\begin{array}{l}\text { Infiltration number }\left(I_{\mathrm{f}}\right) \\
\text { Relief characterization }\end{array}$ & $I_{\mathrm{f}}=F_{\mathrm{s}} * \mathrm{Dd}$ & Faniran (1968) \\
\hline 22 & Height of basin mouth $(z)$ & GIS analysis/DEM & \\
\hline 23 & Maximum height of the basin $(Z)$ & GIS analysis/DEM & \\
\hline 24 & Total basin relief $(H)(\mathrm{m})$ & $H=Z-z$ & Strahler (1952) \\
\hline 25 & Relief ratio $\left(R_{h}\right) \mathrm{m}$ & $\mathrm{Rhl}=H / \mathrm{Lb}$ & Schumm (1956) \\
\hline 26 & Ruggedness number $(R n)$ & $R n=\mathrm{Dd}^{*}(H / 1000)$ & Patton and Baker (1976) \\
\hline 27 & Slop Analysis $(\mathrm{Sa})\left(^{\circ}\right)$ & GIS analysis/DEM & Rich (1916) \\
\hline
\end{tabular}

stream order (Horton 1945). The Betwa River identified as the sixth-order drainage basin; $75.85 \%$ and $20.70 \%$ stream number occurred in the first- and second-order streams, respectively. In upstream, Kaliyasot is the fifth order, Halali and Bina are the fourth order, and Sager is a third-order tributary; in midstream, Jamni is the sixth-order sub-basin, Narain and Orr sub-basins are fifth- and fourth-order subbasins, respectively; and in downstream, Dashan is the fifthorder longest sub-basin and Birma is the smallest measurable fourth-order sub-basin (Fig. 3).

In upstream, midstream and downstream sub-basins showed a large number of the first-order stream indicates terrain complexity and compact bedrock (Vincy et al. 2012). The number of streams decreased in geometric progression as the stream order increased. It indicates that there may be a possibility of sudden flash floods after heavy rainfall in the downstreams (Chitra et al. 2011). Overall impression of a stream number and stream order revealed dendritic drainage pattern in Betwa River basin. The regression plot between a stream number and stream order showed the validity of the law of stream number for the Betwa River basin (Fig. 4).

A stream length ( $\mathrm{Lu})$ states that the total length of stream segments decreases with an increase in the stream order (Horton 1945) and indicates the contributing area of the basin (Magesh et al. 2011). The Betwa River basin showed total stream length of $12,199.65 \mathrm{~km}$ out of which $6318.54 \mathrm{~km}$ was the first order. The Jamni and Dashan contributed $3630.21 \mathrm{~km}$ and $2981.90 \mathrm{~km}$ stream length in the Betwa River basin. These results showed smaller stream length and less permeable bedrocks in the Betwa River basin and sub-basins. Mean stream length (Lsm) varied from 2.12 to $9.35 \mathrm{~km}$ indicating gentle slopes with low gradients of drainage network and coarser texture of the contributing surface. Stream length ratio $\left(R_{\mathrm{L}}\right)$ varied from 0.31 to 0.89 indicating the presence of resistant rock, low slope and topography in the terrain (Bindu et al. 2012). The $R_{\mathrm{L}}$ of Orr, Sagar and Bina tributaries showed an increasing trend from lower order to higher order 
Table 3 Linear aspect of the Betwa River basin and sub-basins

\begin{tabular}{|c|c|c|c|c|c|c|c|}
\hline \multicolumn{8}{|c|}{ Linear aspect of the Betwa River basin } \\
\hline Stream order $(\mathrm{w})$ & $\begin{array}{l}\text { No. of } \\
\text { streams }(\mathrm{Nu})\end{array}$ & $\begin{array}{l}\text { Bifurcation } \\
\text { ratio }(\mathrm{Rb})\end{array}$ & $\begin{array}{l}\text { Mean bifurcation } \\
\text { ratio }(\mathrm{Rbm})\end{array}$ & $\begin{array}{l}\text { Total length of } \\
\text { streams }(\mathrm{Lu})(\mathrm{km})\end{array}$ & $\begin{array}{l}\text { Mean length of } \\
\text { streams }(\mathrm{Lsm})(\mathrm{km})\end{array}$ & $\begin{array}{l}\text { Length ratio } \\
\left(R_{\mathrm{L}}\right)\end{array}$ & $\begin{array}{l}\text { Rho coef- } \\
\text { ficient }(\rho)\end{array}$ \\
\hline \multicolumn{8}{|l|}{ Betwa River basin } \\
\hline 1 & 1568 & & & 6318.54 & & & \\
\hline 2 & 428 & 3.66 & & 2907.06 & & 0.46 & 0.12 \\
\hline 3 & 54 & 7.92 & 4.61 & 1347.73 & 5.9 & 0.46 & 0.06 \\
\hline 4 & 13 & 4.15 & & 823.77 & & 0.61 & 0.15 \\
\hline 5 & 3 & 4.33 & & 453.09 & & 0.54 & 0.12 \\
\hline 6 & 1 & 3 & & 349.43 & & 0.77 & 0.26 \\
\hline Total & 2067 & & & $12,199.65$ & & & \\
\hline \multicolumn{8}{|c|}{ Kaliyasot sub-basin } \\
\hline 1 & 122 & & & 301.43 & & & \\
\hline 2 & 45 & 2.71 & & 149.04 & & 0.5 & 0.18 \\
\hline 3 & 7 & 6.43 & 3.66 & 70.48 & 3.28 & 0.47 & 0.07 \\
\hline 4 & 2 & 3.5 & & 45.67 & & 0.65 & 0.18 \\
\hline 5 & 1 & 2 & & 14.27 & & 0.32 & 0.15 \\
\hline Total & 177 & & & 580.91 & & & \\
\hline \multicolumn{8}{|l|}{ Halali sub-basin } \\
\hline 1 & 38 & & & 158.91 & & & \\
\hline 2 & 9 & 4.22 & & 81.98 & & 0.53 & 0.12 \\
\hline 3 & 2 & 4.5 & 3.57 & 51.06 & 6.42 & 0.61 & 0.14 \\
\hline 4 & 1 & 2 & & 28.84 & & 0.56 & 0.28 \\
\hline Total & 50 & & & 320.80 & & & \\
\hline \multicolumn{8}{|l|}{ Sagar sub-basin } \\
\hline 1 & 31 & & & 233.84 & & & \\
\hline 2 & 7 & 4.43 & 5.71 & 78 & 9.35 & 0.33 & 0.07 \\
\hline 3 & 1 & 7 & & 53 & & 0.67 & 0.09 \\
\hline Total & 39 & & & 364.84 & & & \\
\hline \multicolumn{8}{|l|}{ Bina sub-basin } \\
\hline 1 & 75 & & & 357.16 & & & \\
\hline 2 & 20 & 3.75 & & 176.33 & & 0.49 & 0.13 \\
\hline 3 & 8 & 2.5 & 4.75 & 124.57 & 7.38 & 0.7 & 0.28 \\
\hline 4 & 1 & 8 & & 109.27 & & 0.88 & 0.1 \\
\hline Total & 104 & & & 767.35 & & & \\
\hline \multicolumn{8}{|l|}{ Narain sub-basin } \\
\hline 1 & 219 & & & 522.76 & & & \\
\hline 2 & 81 & 2.7 & & 309.02 & & 0.6 & 0.22 \\
\hline 3 & 17 & 4.77 & 3.92 & 130.57 & 3.33 & 0.42 & 0.09 \\
\hline 4 & 4 & 4.25 & & 60.79 & & 0.46 & 0.11 \\
\hline 5 & 1 & 4 & & 50.23 & & 0.82 & 0.2 \\
\hline Total & 322 & & & 1073.39 & & & \\
\hline \multicolumn{8}{|l|}{ Orr sub-basin } \\
\hline 1 & 48 & & & 268.78 & & & \\
\hline 2 & 16 & 3 & & 130.05 & & 0.49 & 0.16 \\
\hline 3 & 5 & 3.2 & 3.73 & 67.43 & 7.44 & 0.53 & 0.16 \\
\hline 4 & 1 & 5 & & 54.66 & & 0.81 & 0.16 \\
\hline Total & 70 & & & 520.92 & & & \\
\hline \multicolumn{8}{|l|}{ Jamni sub-basin } \\
\hline 1 & 1243 & & & 1818.09 & & & \\
\hline 2 & 355 & 3.5 & & 885.33 & & 0.49 & 0.14 \\
\hline
\end{tabular}


Table 3 (continued)

\begin{tabular}{|c|c|c|c|c|c|c|c|}
\hline \multicolumn{8}{|c|}{ Linear aspect of the Betwa River basin } \\
\hline Stream order $(w)$ & $\begin{array}{l}\text { No. of } \\
\text { streams }(\mathrm{Nu})\end{array}$ & $\begin{array}{l}\text { Bifurcation } \\
\text { ratio }(\mathrm{Rb})\end{array}$ & $\begin{array}{l}\text { Mean bifurcation } \\
\text { ratio }(\mathrm{Rbm})\end{array}$ & $\begin{array}{l}\text { Total length of } \\
\text { streams }(\mathrm{Lu})(\mathrm{km})\end{array}$ & $\begin{array}{l}\text { Mean length of } \\
\text { streams }(\mathrm{Lsm})(\mathrm{km})\end{array}$ & $\begin{array}{l}\text { Length ratio } \\
\left(R_{\mathrm{L}}\right)\end{array}$ & $\begin{array}{l}\text { Rho coef- } \\
\text { ficient }(\rho)\end{array}$ \\
\hline 3 & 51 & 6.96 & & 455.01 & & 0.52 & 0.07 \\
\hline 4 & 9 & 5.67 & 4.42 & 206.84 & 2.12 & 0.46 & 0.08 \\
\hline 5 & 3 & 3 & & 121.67 & & 0.58 & 0.19 \\
\hline 6 & 1 & 3 & & 43.25 & & 0.36 & 0.12 \\
\hline Total & 1662 & & & 3530.21 & & & \\
\hline \multicolumn{8}{|l|}{ Dashan sub-basin } \\
\hline 1 & 463 & & & 1540.76 & & & \\
\hline 2 & 67 & 6.91 & & 803.53 & & 0.53 & 0.07 \\
\hline 3 & 13 & 5.15 & 4.82 & 253.01 & 5.44 & 0.31 & 0.06 \\
\hline 4 & 4 & 3.25 & & 223.59 & & 0.89 & 0.27 \\
\hline 5 & 1 & 4 & & 161.00 & & 0.72 & 0.18 \\
\hline Total & 548 & & & 2981.90 & & & \\
\hline \multicolumn{8}{|l|}{ Birma sub-basin } \\
\hline 1 & 81 & & & 394.61 & & & \\
\hline 2 & 17 & 4.76 & & 189.30 & & 0.49 & 0.1 \\
\hline 3 & 2 & 8.5 & 5.09 & 83.022 & 7.23 & 0.43 & 0.05 \\
\hline 4 & 1 & 2 & & 63.68 & & 0.76 & 0.38 \\
\hline Total & 101 & & & 730.62 & & & \\
\hline
\end{tabular}

indicates the early mature stage of geomorphic development while the remaining sub-basins showed $R_{\mathrm{L}}$ values $<2$ indicating late youth stage of geomorphic development (Thomas et al. 2010; Vittala et al. 2004).

The bifurcation ratio $(\mathrm{Rb})$ is defined as the ratio between the number of streams of the given order to the number of streams of the next higher orders (Strahler 1957). It is a dimensionless property and shows the degree of integration prevailing between streams of various orders in a drainage basin. In the present study, the $\mathrm{Rb}$ varied from 2 to 8.5 , indicating quantitative variations in geological and lithological features of the catchment. The low Rb values in Betwa River basin and sub-basins indicate the flat area with rolling drainage pattern (Horton 1945). The mean bifurcation ratio (4.61) shows that the drainage pattern of the basin has not been affected by structural disturbances. Similar observation was made by many researchers on river basins originating from Vindhyan Supergroup in Central India (Singh et al. 2013).

Rho coefficient $(\rho)$ is the important morphometric parameter which relates drainage density to physiographic development of the basin and also indicates the evaluation of storage capacity of drainage network. Hence, it is a determinant of ultimate degree of drainage development in a given watershed (Horton 1945). Rho is defined as the ratio between stream length ratio and bifurcation ratio. Rho values of Betwa River basin in the range of 0.06-0.26. The Birma sub-basin showed the highest Rho variation ranging from 0.15 to 0.38 , indicating higher hydrological storage during flood periods, and it attenuates the effect of erosion during the elevated discharge (Horton 1945).

\section{Areal aspects}

The areal aspects are the two-dimensional properties of a basin, and the results are listed in Table 4. Following descending orders of areal aspects are given to understand the importance of sub-basins in the formation of Betwa River basin:

$$
\begin{aligned}
& \text { Length: Dashan }>\text { Jamni }>\text { Birma }>\text { Bina }>\text { Orr }>\text { Hal } \\
& \text { ali }>\text { Narain }>\text { Sagar }>\text { Kaliyasot. } \\
& \text { Perimeter: Dashan }>\text { Jamni }>\text { Bina }>\text { Birma }>\text { Orr }>\text { Nar } \\
& \text { ain }>\text { Halali }>\text { Sagar }>\text { Kaliyasot. } \\
& \text { Mean width: Jamni }>\text { Bina }>\text { Birma }>\text { Orr }>\text { Dashan }>\text { Nar } \\
& \text { ain }>\text { Halali }>\text { Sagar }>\text { Kaliyasot. }
\end{aligned}
$$

The length and perimeter showed that the downstream sub-basins (Birma, Jamni and Dashan) were contributing the maximum areal aspects to the Betwa River basin. Further, the Lemniscate's $(k)$ value is an important areal aspect parameter, which is used to determine the slope of the watershed. The $k$ is defined as the ratio of the length of the watershed along the mainstream to the area of the watershed (Chorley 1957). The $k$ value of the Betwa River basin was 4.6 while it ranged from 2.8 to $3.3,2.8$ to 3.6 and 3.6 to 6.8 in upstream, midstream and downstream 

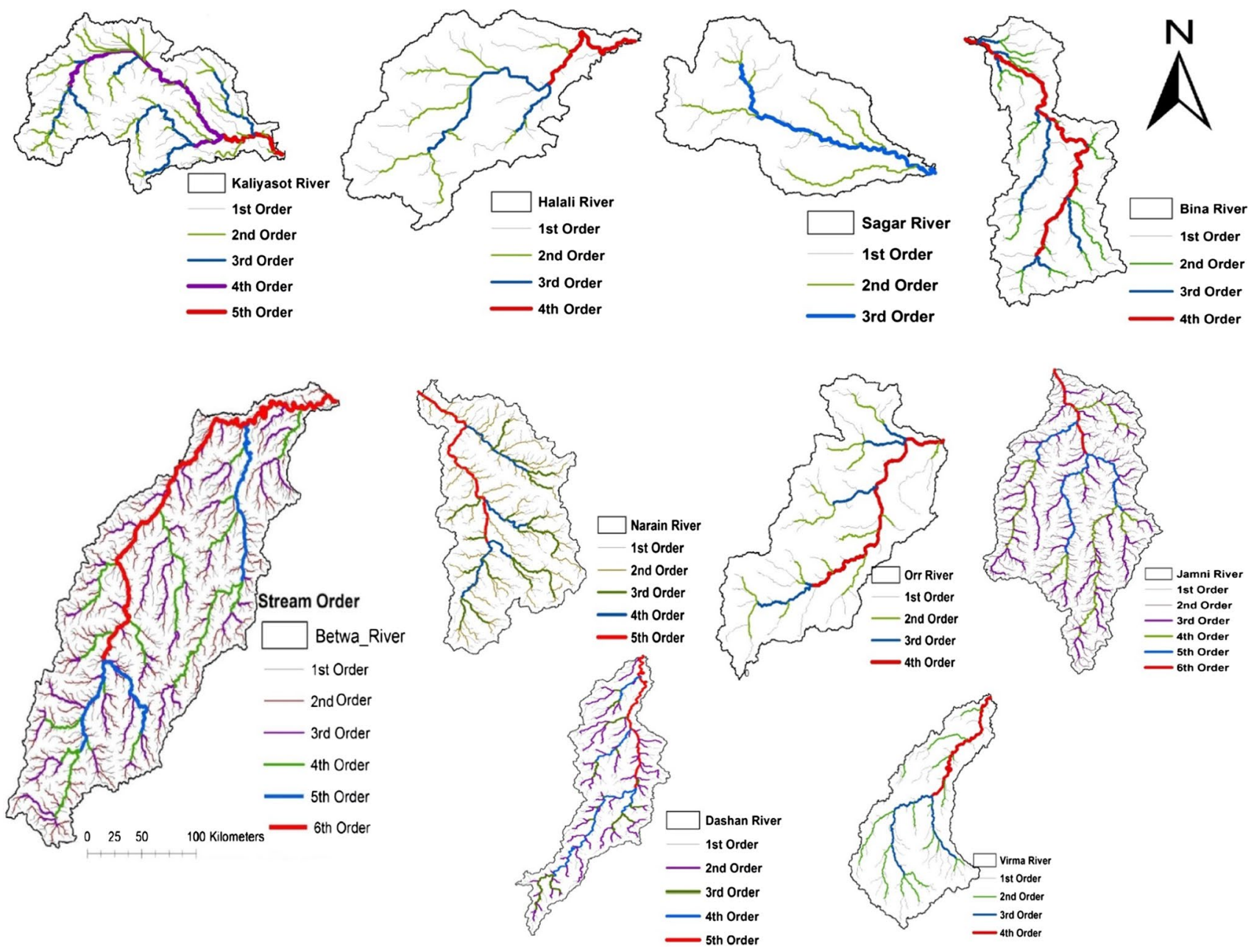

Fig. 3 Drainage and stream order map of the Betwa River basin and sub-basins

Fig. 4 Logarithm regression of stream number against stream order

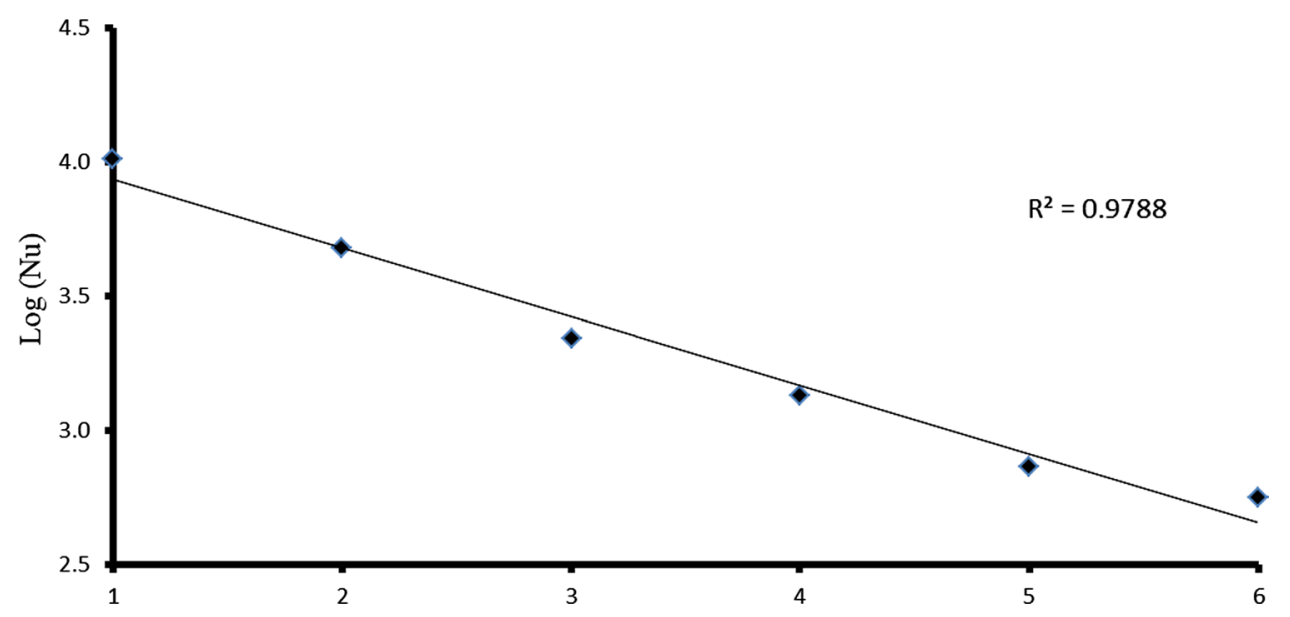


sub-basins, respectively. This shows that upstream occupies the maximum area in its region of inception with a large number of streams.

\section{Drainage texture analysis}

It includes the study of drainage network properties and arrangement of stream engraved into the land surface by a drainage system. The parameters describing drainage texture of Betwa River basin and sub-basins are given in Table 5. Drainage density (Dd) value of the Betwa River basin was calculated as 0.55 . However, in the upstream, midstream and downstream sub-basins, Dd varied from 0.37 to $1.64,0.53$ to 0.57 and 0.16 to 0.46 , respectively. These values are less than 2 , indicating very coarse texture and the presence of both highly weathered and resistant permeable material with low relief. In this study, the drainage texture (Dt) values of Betwa River basin and sub-basins were $<4$, revealed occurrence of coarse texture except Kaliyasot and Narain sub-basins where drainage texture $(>10)$ was classified as fine textured. Stream frequency $\left(F_{\mathrm{s}}\right)$ was $<0.7$, indicating permeable subsurface material and low relief except Kaliyasot and Narain. Circularity ratio $(\mathrm{Rc})$ values of Betwa River basin were computed as 0.13 while it was varied from 0.14 to 0.2 , 0.14 to 0.19 and 0.13 to 0.52 in upstream, midstream and downstream sub-basins, respectively. These low circularity ratios indicate the elongated shape, highly permeable homogenous geologic materials and ephemeral life cycles of the tributaries in Betwa River basin. The constant of channel maintenance $(C)$ is measured as the reciprocal of drainage density $\left(\mathrm{km}^{2} / \mathrm{km}\right)$. The value of $C$ for the

Table 4 Areal aspect of the Betwa River basin and sub-basins

\begin{tabular}{|c|c|c|c|c|c|c|c|c|c|c|}
\hline \multirow[t]{2}{*}{ Parameter(s) } & \multirow[t]{2}{*}{ Betwa } & \multicolumn{4}{|l|}{ Upstream } & \multicolumn{3}{|c|}{ Midstream } & \multicolumn{2}{|c|}{ Downstream } \\
\hline & & Kaliyasot & Halali & Sagar & Bina & Narain & Orr & Jamni & Dashan & Birma \\
\hline Basin length (Lb) (km) & 446 & 44.2 & 63.5 & 50.4 & 95.5 & 61 & 76.2 & 127 & 273 & 96.5 \\
\hline Perimeter $(P)(\mathrm{km})$ & 2071 & 252 & 276 & 213 & 496 & 344 & 357 & 644 & 1683 & 250 \\
\hline Mean basin width $(\mathrm{Wb})(\mathrm{km})$ & 98.7 & 16.04 & 18.71 & 16.7 & 29.5 & 22.4 & 25.8 & 35.6 & 64.7 & 26.6 \\
\hline Basin area $\left(\mathrm{km}^{2}\right)(A)$ & 44,002 & 709 & 1188.00 & 841 & 2812.00 & 1363 & 1959 & 4519 & 28,858 & 2566 \\
\hline Lemniscate's $(k)$ & 4.6 & 2.8 & 3.3 & 3.0 & 3.2 & 2.8 & 3.0 & 3.6 & 6.8 & 3.7 \\
\hline
\end{tabular}

Table 5 Results of drainage texture analysis of Betwa River basin and sub-basins

\begin{tabular}{|c|c|c|c|c|c|c|c|c|c|c|}
\hline \multirow[t]{2}{*}{ Parameter(s) } & \multirow[t]{2}{*}{ Betwa } & \multicolumn{4}{|l|}{ Upstream } & \multicolumn{3}{|c|}{ Midstream } & \multicolumn{2}{|c|}{ Downstream } \\
\hline & & Kaliyasot & Halali & Sagar & Bina & Narain & Orr & Jamni & Dashan & Birma \\
\hline Drainage density $(D)$ & 0.55 & 1.64 & 0.54 & 0.37 & 0.55 & 1.58 & 0.53 & 1.56 & 0.21 & 0.57 \\
\hline Stream frequency $\left(F_{\mathrm{s}}\right)$ & 0.45 & 3.90 & 0.43 & 0.20 & 0.43 & 3.72 & 0.44 & 0.62 & 0.16 & 0.46 \\
\hline Drainage texture (Dt) & 9.62 & 10.97 & 1.85 & 1.08 & 2.45 & 14.75 & 2.40 & 4.34 & 2.82 & 4.74 \\
\hline Circularity ratio $(\mathrm{Rc})$ & 0.13 & 0.14 & 0.20 & 0.19 & 0.14 & 0.14 & 0.19 & 0.14 & 0.13 & 0.52 \\
\hline $\begin{array}{l}\text { Constant of channel } \\
\text { maintenance }(C)\end{array}$ & 1.80 & 0.61 & 1.85 & 2.68 & 1.83 & 0.63 & 1.89 & 0.64 & 4.83 & 1.76 \\
\hline Infiltration number $\left(I_{\mathrm{f}}\right)$ & 0.82 & 2.38 & 0.80 & 0.53 & 0.79 & 2.36 & 0.83 & 0.40 & 0.79 & 0.81 \\
\hline
\end{tabular}

Table 6 Relief characteristics of Betwa River basin and sub-basins

\begin{tabular}{|c|c|c|c|c|c|c|c|c|c|c|}
\hline \multirow[t]{2}{*}{ Parameter(s) } & \multirow[t]{2}{*}{ Betwa } & \multicolumn{4}{|l|}{ Upstream } & \multicolumn{3}{|c|}{ Midstream } & \multicolumn{2}{|c|}{ Downstream } \\
\hline & & Kaliyasot & Halali & Sagar & Bina & Narain & Orr & Jamni & Dashan & Birma \\
\hline Height of the basin mouth $z(\mathrm{~m})$ & 471 & 563 & 497 & 458 & 546 & 509 & 458 & 419 & 496 & 531 \\
\hline Maximum height of the basin $Z$ (m) & 710 & 653 & 615 & 538 & 710 & 640 & 538 & 580 & 700 & 653 \\
\hline Total basin relief $\mathrm{H}(\mathrm{m})$ & 239 & 90 & 118 & 80 & 164 & 131 & 80 & 161 & 204 & 122 \\
\hline Relief ratio Rhl (m) & 0.54 & 2.04 & 1.86 & 1.05 & 1.72 & 2.15 & 1.05 & 1.27 & 0.46 & 1.26 \\
\hline Ruggedness number $R n$ & 0.13 & 0.09 & 0.03 & 0.01 & 0.04 & 0.21 & 0.02 & 0.13 & 0.04 & 0.03 \\
\hline
\end{tabular}




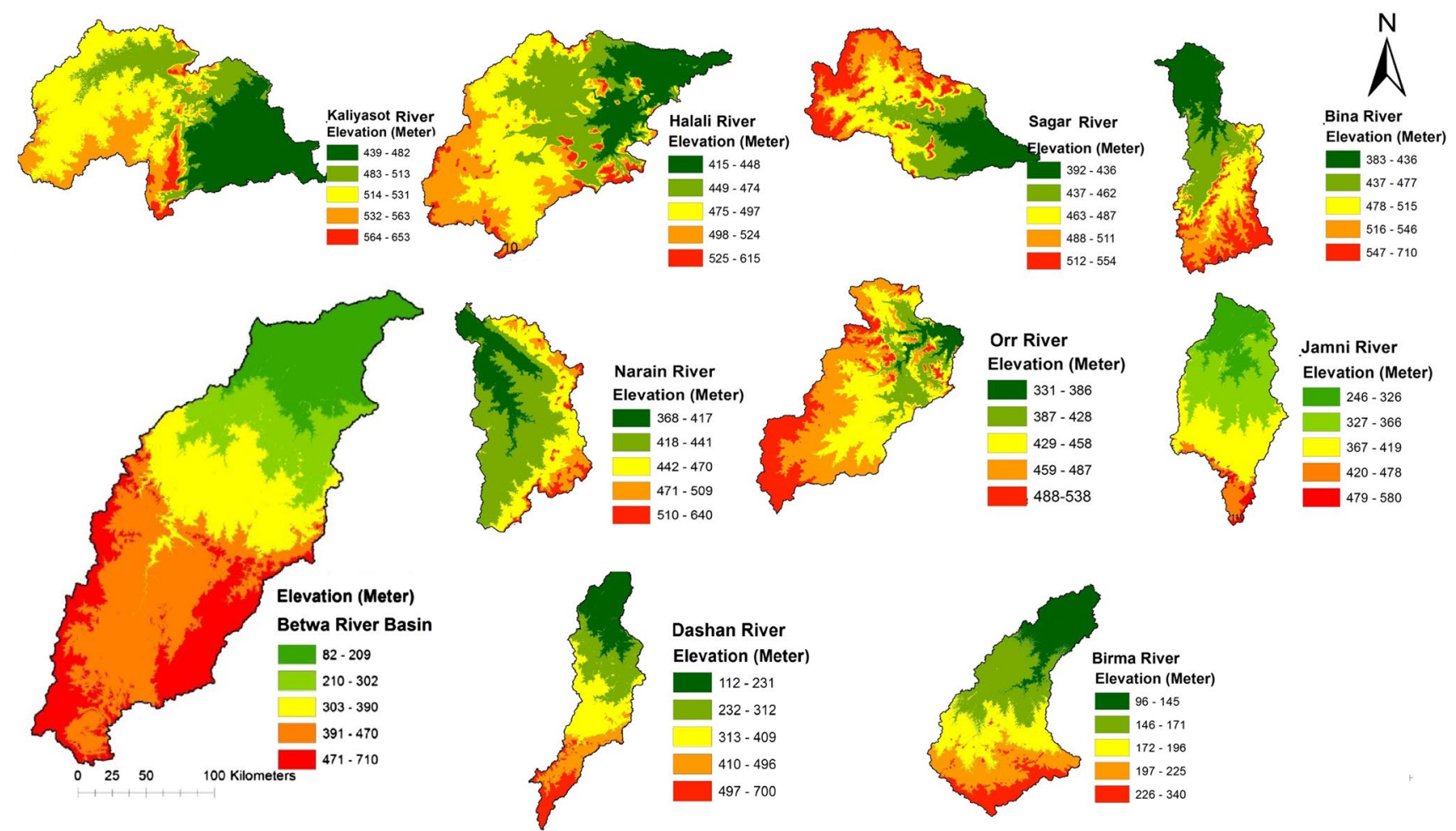

Fig. 5 Elevation map of the Betwa River basin and sub-basins

Betwa River basin is calculated as $1.80 \mathrm{~km}^{2} / \mathrm{km}$. The $C$ varied from 0.61 to $2.68,0.61$ to 2.68 and 1.76 to 1.86 in upstream, midstream and downstream regions, respectively. Most of the sub-watersheds with higher values indicate the region with significantly higher infiltration rates. The infiltration number $\left(I_{\mathrm{f}}\right)$ values for the Betwa River basin and sub-basins showed low runoff and high infiltration capacity.

\section{Relief characterization}

Relief parameters consider as three-dimensional features of the drainage basin, generally depends on the maximum and minimum height of the basin (Table 6). The total relief of Betwa River basin was $239 \mathrm{~m}$ (Fig. 5). The total relief of the tributaries ranged from 80 to $164 \mathrm{~m}, 80$ to $161 \mathrm{~m}$ and 122 to $204 \mathrm{~m}$, in upstream, midstream and downstream regions, respectively. These values indicated high infiltration and low runoff conditions in the study area. Similar observations were made by Pandey and Das (2016) in Usri River basin of Chhota Nagpur Plateau in India. The relief ratio $\left(R_{h}\right)$ of the Betwa River basin was 0.54 , indicating large drainage areas. The $R_{h}$ of upstream and midstream tributaries ranged from 1.05 to 2.04 and 1.05 to 2.15 , respectively, indicating steep slope and high relief. Ruggedness number $(R n)$ value of Betwa River basin was 0.13 while the $R n$ values of tributaries ranges from 0.01 to 0.09 , 0.02 to 0.21 and 0.03 to 0.04 , respectively, in upstream, midstream and downstream regions. The relatively low values of $R n$ indicate mature river basin with long drainage density and gentle slope which resulted in less erosional susceptibility in the study area. Pandey and Das (2016) reported that homogenous lithology, gentle regional slope and lack of structural control were responsible for low values of $R n$. The high $R n$ values were reported in the Western Ghats region indicates the structural complexity of terrain is highly susceptible to erosion (Samal et al. 2015).

Slope map for Betwa and sub-basins were prepared from SRTM DEM (Fig. 6). The slope classification is divided into seven classes (Table 7). The $>74.5 \%$ of the area is under $<3^{\circ}$ slope indicates near level to gentle terrain condition. The highest mean basin slope was observed in Kaliyasot (upstream), Jamni (midstream) and Dashan (downstream), indicating that eastern region of the Betwa River basin was ecohydrologically significant for stream 

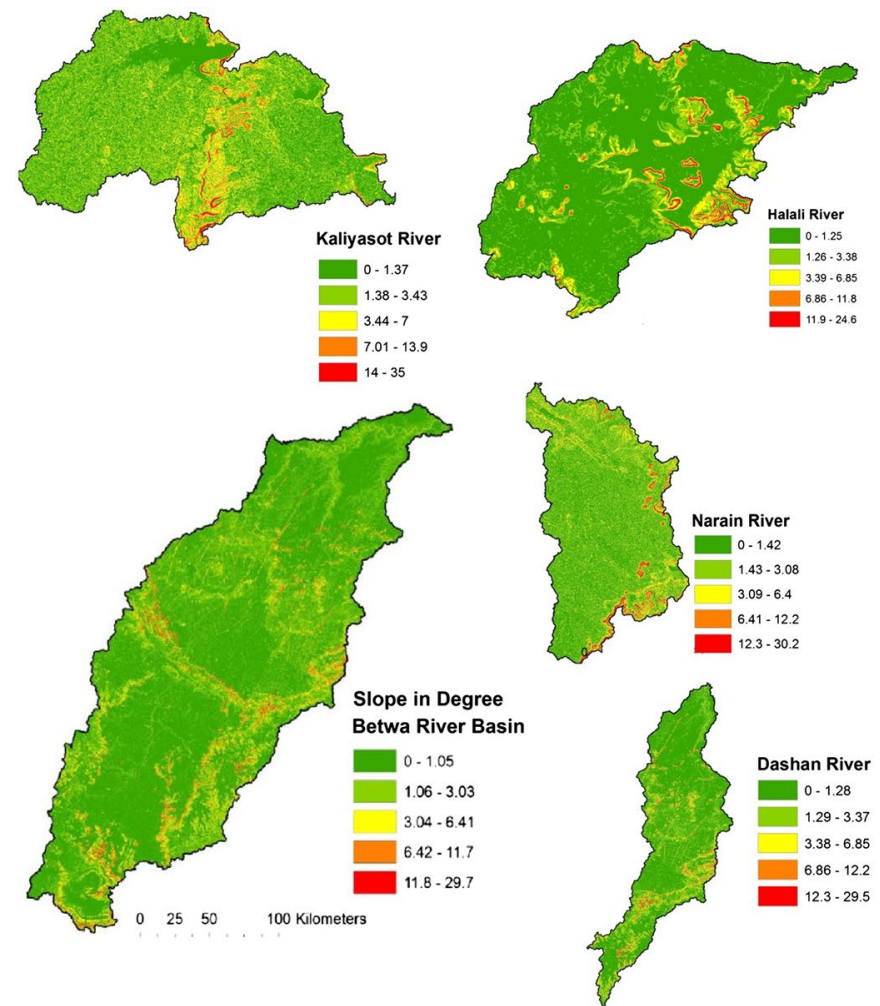

Fig. 6 Slope map of the Betwa River basin and sub-basins

network generation, runoff and flooding. The midstream region was intersected by the east-west ridge of Bundelkhand granites covered with tropical deciduous forests, which alter the perennial stream flow velocity, soil erosion, sedimentation and hydrograph rise in the study area. This might be responsible for spatial variation in flooding scenario in the Betwa River basin. The aspect map derived from SRTM DEM represents the compass direction of the aspect (Fig. 7). Betwa River basin showed 37.3\% NE-E-SE aspect of slope (Table 8) which is exposed to the sun during the hottest time day, consequently warmer than the aspect on other side (Al-Saady et al. 2016).

Table 7 Slope classes in Betwa River basin according to IMSD classification

\begin{tabular}{lllcc}
\hline Slope categories & Slope $(\%)$ & Slope $\left(^{\circ}\right)$ & Area $\left(\mathrm{km}^{2}\right)$ & Area $(\%)$ \\
\hline Nearly level & $<1$ & $<0.39$ & $16,518.2$ & 37.54 \\
Very gentle & $1-3$ & $0.39-1.19$ & $16,304.5$ & 37.05 \\
Gentle & $3-5$ & $1.19-1.98$ & 7844.2 & 17.8 \\
Moderate & $5-10$ & $1.98-3.97$ & 2041.5 & 4.63 \\
Strong & $10-15$ & $3.97-5.95$ & 793.1 & 1.80 \\
Moderately steep- & $15-35$ & $5.95-13.90$ & 370.0 & 0.84 \\
$\quad$ steep & & & & \\
Very steep & $<35$ & $<13.90$ & 129.7 & 0.29 \\
\hline
\end{tabular}
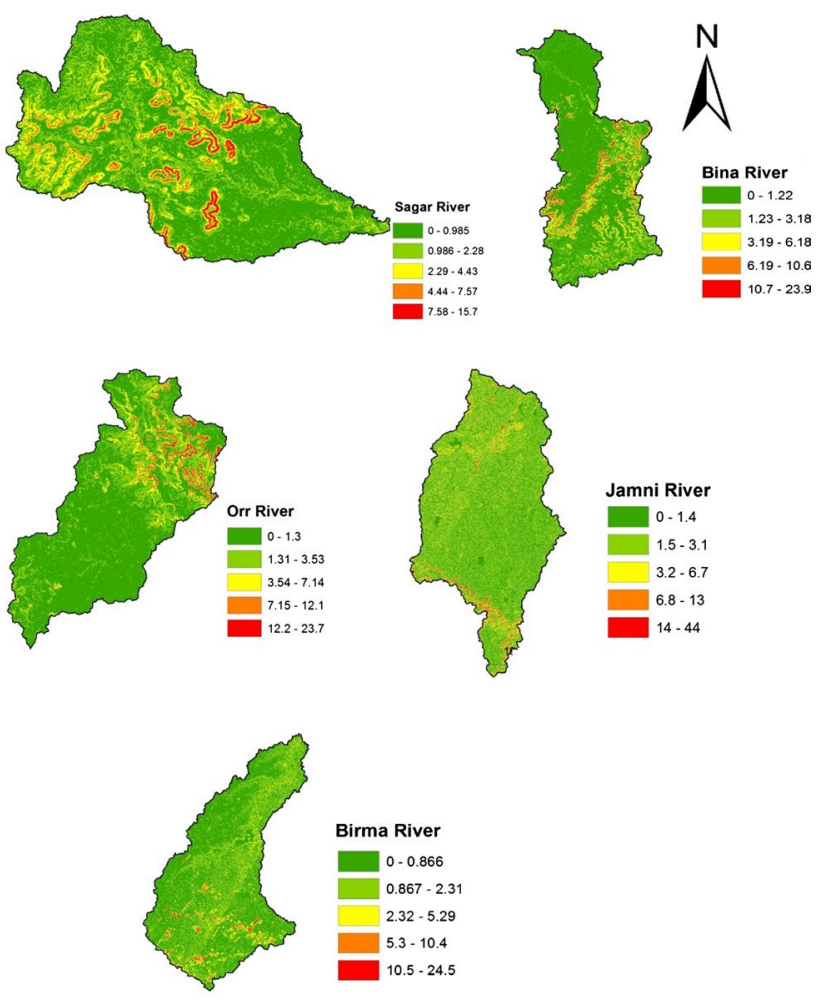

\section{Conclusions}

The morphometric analysis shows dendritic drainage patterns, coarser drainage texture, low runoff and low erosional potential in BRB. The study area is characterized with low discharge of surface runoff and highly permeable subsoil conditions. Dominant slope is east facing, gentle and laden with high moisture content and lower evaporation rate in the basin. The high moisture content in the east-facing slope may be subjected to high weathering than the dry slopes, and this condition may alter the stream channel morphology. The sub-basin morphometric analysis reveals that the northeast and central part of the Betwa River basin needs immediate attention for the watershed conservation. These regions are important perennial source of running water in Central India and middle Gangetic plain. The morphometric data can be integrated with land use/cover, landforms, geology, water level and soil in the GIS domain to identify hot-spots for soil and water conservation structures at local and regional scales. In nutshell, this study can be used in future to delineate the carrying capacity of Betwa River basin and forecast changes in the sediment transport to the Bay of Bengal through Ganga River basin. 

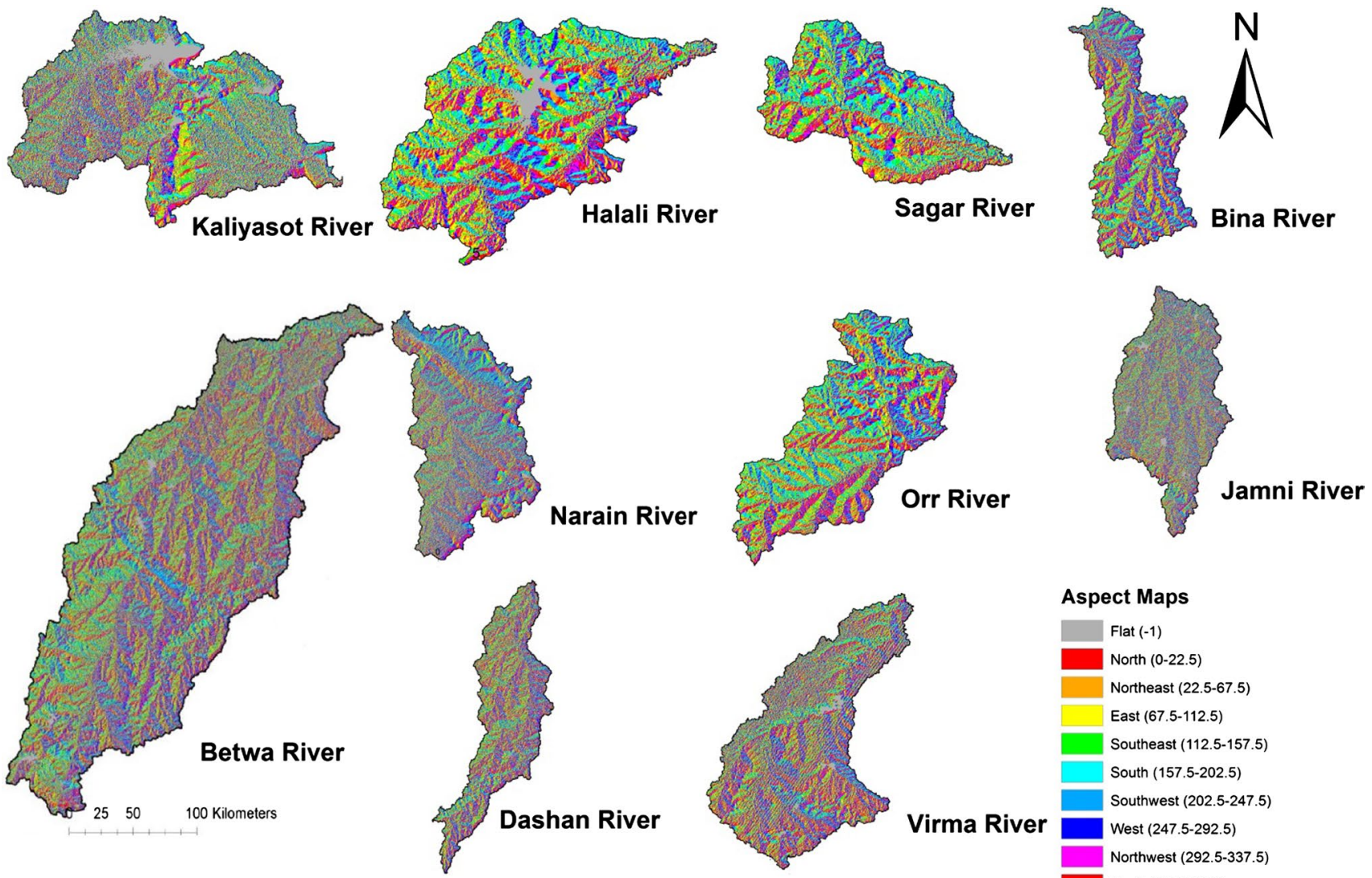

\section{Aspect Maps}

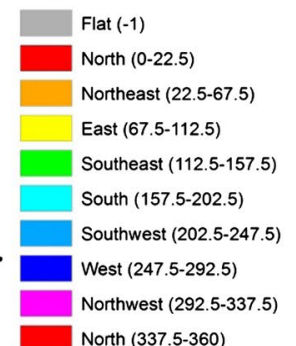

Fig. 7 Aspect map of the Betwa River basin and sub-basins

Table 8 Areal extent of aspect in the Betwa River basin

\begin{tabular}{lllll}
\hline Value & Count & Aspect & Area $\left(\mathrm{km}^{2}\right)$ & Area $(\%)$ \\
\hline 1 & 670,396 & Flat & 613.6859 & 1.4 \\
2 & $6,640,375$ & N & 6078.653 & 13.8 \\
3 & $6,134,687$ & NE & 5615.742 & 12.8 \\
4 & $6,011,738$ & E & 5503.194 & 12.5 \\
5 & $5,770,606$ & SE & 5282.46 & 12.0 \\
6 & $5,258,728$ & S & 4813.882 & 10.9 \\
7 & $5,299,545$ & SW & 4851.246 & 11.0 \\
8 & $5,356,215$ & W & 4903.123 & 11.1 \\
9 & $6,925,049$ & NW & 6339.246 & 14.4 \\
\hline
\end{tabular}

Acknowledgements Authors are grateful to Department of Science and Technology (DST), Government of India, for funding Ph.D. of Mr. Madavi Venkatesh (2016DR0105) under the research Project No. DST(121)/15-16/429/ESE. We are also grateful to the Department of Environmental Science and Engineering, IIT(ISM), Dhanbad, for providing the logistic support to carry out field monitoring and laboratory analysis.

\section{Compliance with ethical standards}

Conflict of interest The authors declare that there is no conflict of interests regarding the publication of this paper.
Open Access This article is distributed under the terms of the Creative Commons Attribution 4.0 International License (http://creativeco mmons.org/licenses/by/4.0/), which permits unrestricted use, distribution, and reproduction in any medium, provided you give appropriate credit to the original author(s) and the source, provide a link to the Creative Commons license, and indicate if changes were made.

\section{References}

Abboud IA, Nofal RA (2017) Morphometric analysis of wadi Khumal basin, western coast of Saudi Arabia, using remote sensing and GIS techniques. J Afr Earth Sci 126:58-74

Al-Saady YI, Al-Suhaill QA, Al-Tawash BS, Othman AA (2016) Drainage network extraction and morphometric analysis using remote sensing and GIS mapping techniques (Lesser Zab River Basin, Iraq and Iran). Environ Earth Sci 75(18):1243

Ameri AA, Pourghasemi HR, Cerda A (2018) Erodibility prioritization of sub-watersheds using morphometric parameters analysis and its mapping: a comparison among TOPSIS, VIKOR, SAW, and CF multi-criteria decision making models. Sci Total Environ 613:1385-1400

Angillieri MYE (2012) Morphometric characterization of the Carrizal basin applied to the evaluation of flash floods hazard, San Juan, Argentina. Quat Int 253:74-79

Avinash K, Jayappa KS, Deepika B (2011) Prioritization of subbasins based on geomorphology and morphometric analysis using remote sensing and geographic information system (GIS) techniques. Geocarto Int 26(7):569-592 
Bali R, Agarwal KK, Ali SN, Rastogi SK, Krishna K (2012) Drainage morphometry of Himalayan Glacio-fluvial basin, India: hydrologic and neotectonic implications. Environ Earth Sci 66(4):1163-1174

Bindu G, Neelkantan R, Ragunath R (2012) Assessment of morphometric characteristics of Chittar river basin, Triruvantpuram district, Kerala: a remote sensing and GIS based study. Indian J Geomorphol 1:127-132

Chorley RJ (1957) Illustrating the laws of morphometry. Geol Mag 94(2):140-150

Chitra C, Alaguraja P, Ganeshkumari K, Yuvaraj D, Manivel M (2011) Watershed characteristics of Kundah sub basin using remote sensing and GIS techniques. Int J Geomat Geosci 2(1):311

Faniran A (1968) The index of drainage intensity-a provisional new drainage factor. Aust J Sci 31:328-330

Horton RE (1932) Drainage-basin characteristics. Eos Trans Am Geophys Union 13(1):350-361

Horton RE (1945) Erosional development of streams and their drainage basins; hydrophysical approach to quantitative morphology. Geol Soc Am Bull 56(3):275-370

Kabite G, Gessesse B (2018) Hydro-geomorphological characterization of Dhidhessa River Basin, Ethiopia. Int Soil Water Conserv Res 6(2):175-183

Kumar B, Venkatesh M, Triphati A, Anshumali (2017) A GIS-based approach in drainage morphometric analysis of Rihand River Basin, Central India. Sustain Water Resour Manag 4(1):45-54

Leopold LB, Wolman MG, Miller JP (1964) Fluvial process in geomorphology. W H Freeman, Sanfransisco

Magesh NS, Chandrasekar N, Soundranayagam JP (2011) Morphometric evaluation of Papanasam and Manimuthar watersheds, parts of Western Ghats, Tirunelveli district, Tamil Nadu, India: a GIS approach. Environ Earth Sci 64(2):373-381

Malviya VP, Arim M, Pati JK, Kaneko Y (2006) Petrology and geochemistry of metamorphosed basaltic pillow lava and basaltic komatiite in the Mauranipur area: subduction related volcanism in the Archean Bundelkhand craton, Central India. J Mineral Petrol Sci 101(4):199-217

Miller VC (1953) A quantitative geomorphic study of drainage basin characteristics in the clinch mountain area. Technical report-3, Depart of Geol Columbia University

Patton PC, Baker VR (1976) Morphometry and floods in small drainage basins subject to diverse hydrogeomorphic controls. Water Resour Res 12:941-952

Pandey PK, Das SS (2016) Morphometric analysis of Usri River basin, Chhotanagpur Plateau, India, using remote sensing and GIS. Arab Jour Geosci 9(3):240

Panda B, Venkatesh M, Kumar B, Anshumali (2018) A GIS-based approach in drainage and morphometric analysis of Ken River basin and sub-basins, Central India. J Geol Soc India 93(1):75-84

Patel A, Katiyar SK, Prasad V (2016) Performances evaluation of different open source DEM using differential global positioning system (DGPS). Egypt J Remote Sens Space Sci 19(1):7-16

Pati JK, Patel SC, Pruseth KL, Malviya VP, Arima M, Raju S, Pati P, Prakash K (2007) Geology and geochemistry of giant quartz veins from the Bundelkhand Craton, Central India and their implications. J Earth Syst Sci 116(6):497-510
Rabus B, Eineder M, Roth A, Bamle R (2003) The shuttle radar topography mission - a new class of digital elevation models acquired by spaceborne radar. ISPRS J Photogramm Remote Sens 57(4):241-262

Rich JL (1916) A geographical method of determining the average inclination of a land surface from a contour map. Trans Ill State Acad Sci 9:195

Ray JS (2006) Age of the Vindhyan Supergroup: a review of recent findings. J Earth Syst Sci 115(1):149-160

Schumm SA (1956) Evolution of drainage systems and slopes in badlands at Perth Amboy, New Jersey. Geol Soc Am Bull 67:597-646

Samal DR, Gedam SS, Nagarajan R (2015) GIS based drainage morphometry and its influence on hydrology in parts of Western Ghats region, Maharashtra, India. Geocarto Int 30(7):755-778

Singh P, Thakur JK, Singh UC (2013) Morphometric analysis of Morar River Basin, Madhya Pradesh, India, using remote sensing and GIS techniques. Environ Earth Sci 68(7):1967-1977

Singh P, Gupta A, Singh M (2014) Hydrological inferences from watershed analysis for water resource management using remote sensing and GIS techniques. Egypt J Remote Sens Space Sci 17(2):111-121

Strahler AN (1964) Quantitative geomorphology of drainage and channel networks. In: Fairbridge RW (ed) The encyclopedia of geomorphology, Encyclopedia of earth science studies. McGraw-Hill Book Co, New York, pp 39-73

Strahler AN (1952) Dynamic basis of geomorphology. Geol Soc Am Bull 63(9):923-938

Strahler AN (1957) Quantitative analysis of watershed geomorphology. Eos Trans Am Geophys Union 38(6):913-920

Thomas J, Joseph S, Thrivikramaji KP (2010) Morphometric aspects of a small tropical mountain river system, the southern Western Ghats, India. Int J Digit Earth 3(2):135-156

Thomas J, Joseph S, Thrivikramji KP, Abe G (2011) Morphometric analysis of the drainage system and its hydrological implications in the rain shadow regions, Kerala, India. J Geogr Sci 21(6):1077-1088

Vincy MV, Rajan B, Pradeepkumar AP (2012) Geographic information system-based morphometric characterization of sub-watersheds of Meenachil river basin, Kottayam district, Kerala, India. Geocarto Int 27(8):661-684

Vittala SS, Govindaiah S, Gowda HH (2004) Morphometric analysis of sub-watersheds in the Pavagada area of Tumkur district, South India using remote sensing and GIS techniques. J Indian Soc Remote Sens 32(4):351-362

Yadav SK, Singh SK, Gupta M, Srivastava PK (2014) Morphometric analysis of Upper Tons basin from Northern Foreland of Peninsular India using CARTOSAT satellite and GIS. Geocarto Int 29(8):895-914

Publisher's Note Springer Nature remains neutral with regard to jurisdictional claims in published maps and institutional affiliations. 